\title{
Impact of the North Atlantic Oscillation on European aerosol ground levels through local processes: a seasonal model-based assessment using fixed anthropogenic emissions
}

\author{
S. Jerez ${ }^{1}$, P. Jimenez-Guerrero ${ }^{2}$, J. P. Montávez ${ }^{2}$, and R. M. Trigo ${ }^{1}$ \\ ${ }^{1}$ Instituto Dom Luiz, University of Lisbon, Portugal \\ ${ }^{2}$ Department of Physics, Regional Campus of International Excellence “Campus Mare Nostrum”, University of Murcia, Spain
}

Correspondence to: S. Jerez (sonia.jerez@gmail.com)

Received: 7 May 2013 - Published in Atmos. Chem. Phys. Discuss.: 27 May 2013

Revised: 13 October 2013 - Accepted: 21 October 2013 - Published: 18 November 2013

\begin{abstract}
The North Atlantic Oscillation (NAO) controls a large amount of the European climate variability with asymmetric impacts in both time and space. Here we investigate how the NAO impact on the local atmospheric processes (disregarding the NAO impact on the large intercontinental transport mechanisms) influences the levels of various aerosol species using simulated data under constant emissions, which are fixed to the 2005 levels in order to avoid anthropogenic-induced signals. In particular, we analyze interannual variations at the seasonal timescale and focus on the ground-level. The results show that positive NAO phases favor increased aerosol concentrations in southern (northern) regions during winter (summer), while negative NAO phases enhance them in northern (southern) regions during winter (summer). The underlying processes are clearly related to the NAO impact on precipitation and wind, as they act to clean the atmosphere through removal and dispersion processes, and to the NAO impact on the radiation balance (i.e., cloudiness) as it affects the biogenic emitting activity and on the oxidative capacity of the atmosphere. Differences for all the species studied (natural inert, secondary inorganic and organic aerosols) are up to $5 \mu \mathrm{g} \mathrm{m}^{-3}$, reaching 10 and $20 \mu \mathrm{g} \mathrm{m}^{-3}$ for $\mathrm{PM}_{10}$ and $\mathrm{PM}_{2.5}$ respectively, which represents variations of about $20-40 \%$ in their mean levels between opposite NAO phases.
\end{abstract}

\section{Introduction}

Air pollution is a major environmental and health problem affecting industrialized and developing countries around the world. Main detrimental consequences of the exposure of humans to photochemical and particulate matter pollution include respiratory difficulties, especially for sensitive people (Pope and Dockery, 2006). The results of the APHEIS study (Ballester et al., 2008) indicate that atmospheric pollution causes the premature death of over 310000 dwellers in the European Union each year. The most serious problems in Europe are related with particulate matter with a diameter of less than $10 \mu \mathrm{m}\left(\mathrm{PM}_{10}\right)$, nitrogen dioxide and ozone. In this sense, worldwide epidemiological studies show a consistent increase in cardiac and respiratory morbidity and mortality from exposure to air pollution (e.g., Pope et al., 2009). Besides, ecosystems are also affected, with losses of agricultural crops and damages in aquatic and terrestrial ecosystems having been reported (Van Dingenen et al., 2009). In order to anticipate when and why episodes of air pollution arise and how they can be abated, reliable estimations of air pollution levels and a better understanding of the chemicophysical processes behind them are crucial.

Air pollution levels depend on both emissions (either natural or anthropogenic) and the atmospheric conditions steering and transforming them through processes related to chemistry, transport and removal (Jacob and Winner, 2009). Precipitation provokes wet deposition, hence favoring the removal of airborne pollutants, and wind favors their transport and dispersion, although enhanced winds also promote the formation of marine aerosols over the water mass areas. 
On the other hand, radiation levels and temperature play a major role on gas-phase chemistry through the photolysis of primary and secondary pollutants (see e.g., Katragkou et al., 2010; Forkel et al., 2012; Jiménez-Guerrero et al., 2012; Meier et al., 2012; Colette et al., 2013; Hedegaard et al., 2013; as recent works on the topic), determining also the vegetation activity and thereby modifying natural emissions.

Despite the great climate heterogeneity and variability that characterizes Europe, just a few large-scale teleconnection modes control a large amount of it (Trigo et al., 2008). In particular, many studies establish the fundamental role of the North Atlantic Oscillation (NAO) in this regard, affecting especially western Europe with an asymmetric impact between northern and southern areas (Osborn et al., 1999; Wanner et al., 2001; Trigo et al., 2002, 2008). The NAO pattern consists of a meridional gradient in sea level pressure (SLP) over the North Atlantic with centers roughly around the Azores Islands (high pressures) and near Iceland (low pressures). During its positive phases $\left(\mathrm{NAO}^{+}\right)$, such a dipole in SLP is enhanced with the consequent intensification of westerly winds in northern Europe associated with an intensified jet stream. This configuration promotes also the steering of most storms over northern regions, advecting humid air from the ocean, hence favoring cloudiness and precipitation. Contrary and consistently, $\mathrm{NAO}^{+}$reduces cloudiness and precipitation in southern Europe. Conversely, the intense zonal circulation promoted by the negative NAO phases $\left(\mathrm{NAO}^{-}\right)$enhances the westerly flow penetrating in southern Europe through the Iberian Peninsula (Jerez et al., 2013b) and extending until eastern Europe, and allows cyclones to follow more southern paths within the European continent (Trigo, 2006). Most studies have focused their analysis on NAO-climate links during the winter season, where the SLP gradient is stronger and the climatic impact of this large-scale mode of variability extends to Eurasia (Wanner et al., 2001; Trigo et al., 2002) but also North America, Greenland, the Arctic and North Atlantic oceans (Hurrell and van Loon, 1997). Readers looking for comprehensive reviews of the dynamics of the NAO and associated impacts should consult the books by Hurrell et al. (2003), and Vicente-Serrano and Trigo (2011). However, recent works have shown that the summer NAO still plays an important role on shaping the climate of northern and central Europe (albeit less relevant than in winter) including parts of the Mediterranean Basin (Folland et al., 2009; Bladé et al., 2012).

These NAO-related impacts on the atmospheric fields are bound to inflict an important impact on air pollution levels (Dayan et al., 2008; Sanchez-Lorenzo et al., 2008; Chiacchio and Wild, 2010), particularly on aerosol concentrations. This influence should arise through both local processes and large-scale air pollutants transport. For instance, Eckhardt et al. (2003) showed that $\mathrm{NAO}^{+}$enhances northward transport of pollutants from Europe to Arctic regions, mainly in winter and spring, compared to $\mathrm{NAO}^{-}$phases. At the same time, $\mathrm{NAO}^{+}$promotes African dust intrusions into southwestern
European regions (which occurs mostly in the summertime) as the westerly winds associated to $\mathrm{NAO}^{-}$events prevent subtropical air masses to reach the European midlatitudes; although, on the other hand, these $\mathrm{NAO}^{-}$related large-scale zonal winds also favor the transport of pollutants from North America to Europe (Moulin et al., 1997; Dayan, 2011; Christoudias et al., 2012; Cusack et al., 2012; Pey et al., 2013). But the signature of the NAO in the climatic conditions (and thereby on air pollution levels) is not restricted to changes in the large-scale circulation patterns, as these have also repercussions on other atmospheric variables such as precipitation and temperature, as commented above, with a potential subsequent impact on air quality through local processes such as aerosol wet deposition. However, since few studies have been devoted to explore air pollution levels from a climatic perspective, and even less are those disentangling between local and large-scale mechanisms, the contribution of the local NAO-controlled processes on the climatology of air pollution levels is still hardly established.

Hence, the objective of the present study is to increase the understanding of the signature of the NAO in terms of mean concentration of aerosols in a region covering the entire Mediterranean Basin, from northern Africa to northern Europe, with the focus on elucidating the influence of the small-scale processes. To achieve this goal, we use a numerical simulation of the atmospheric chemical composition that spans three decades of the recent past without considering variations in the anthropogenic emissions, thus allowing to isolate the natural variations in the aerosol levels. The simulation was designed to disregard the signals from the NAO impact on the long-range transport by using constant climatological boundary conditions for the aerosol concentrations. This design does not provide a full realistic picture, but allows us to improve our understanding of the role of the local underlying mechanisms as they are governed by the NAO.

The structure of this work is as follows. Section 2 describes the modeling system and the experimental setup. Section 3 provides the methodology. Section 4 presents the results. Finally, Sect. 5 summarizes the main conclusions.

\section{Data}

\subsection{Air-quality modeling system}

The modeling system consists of a climatic version of the Fifth-Generation Pennsylvania State University - National Center for Atmospheric Research Mesoscale Model (MM5) (Grell et al., 1994) driven by the ECMWF ERA40 reanalysis (Uppala et al., 2005), when available, or by ECMWF analysis data when not (boundary conditions were updated every $6 \mathrm{~h}$ without nudging), coupled offline to the CHIMERE chemistry transport model (Bessagnet et al., 2004; Rouil et al., 2009). The MELCHIOR2 gas-phase mechanism is implemented within CHIMERE (Derognat et al., 2003). The 
chemistry transport model includes aerosol and heterogeneous chemistry, distinguishing among different chemical aerosol components, namely nitrate, sulfate, ammonium, elemental and organic carbon with three subcomponents (primary, secondary anthropogenic and secondary biogenic) and marine aerosols. Unspecified primary anthropogenic aerosols and aerosol water are additionally kept as separate components. The model considers the thermodynamic equilibrium using the ISORROPIA model (Nenes et al., 1998). Lastly, the aerosol microphysical description for CHIMERE is based on a sectional aerosol module including 6 bins from $10 \mathrm{~nm}$ to $40 \mu \mathrm{m}$ using a geometrical progression. Although technical details of the modeling system setup can be found in Jiménez-Guerrero et al. (2011, 2012), we provide below a brief description of its main characteristics and further references supporting its ability.

The CHIMERE domain considered in the modeling system covers all the Mediterranean Basin extending to northern Europe with a spatial resolution of $0.2^{\circ}$ in the horizontal, which is around $25 \mathrm{~km}$ at the European latitudes considered, and eight vertical levels unevenly spaced up to 550 $\mathrm{hPa}$. This resolution is higher than usual in climate runs (Carvalho et al., 2010; Katragkou et al., 2010; Jiménez-Guerrero et al., 2011; Juda-Rezler et al., 2012; Manders et al., 2012). Although the CHIMERE time step was $3 \mathrm{~h}$, outputs were recorded every $6 \mathrm{~h}$.

The fields from MM5 (provided every $12 \mathrm{~h}$ with a spatial resolution of $90 \mathrm{~km}$ ) are bilinearly interpolated to the CHIMERE working grid. The MM5 setup used here is the same as in Gomez-Navarro et al. (2011). Detailed descriptions of the climate modeling system used and its skill to realistically reproduce regional climatic features, such as temperature and precipitation annual cycles or the interaction between the large-scale circulation and the orography, which largely modulates the rainfall patterns having an important influence on air quality, can be found there and in Jerez et al. (2013a). Although these two works focus only on the Iberian Peninsula, there is extensive literature demonstrating the ability of similar MM5 modeling systems for reproducing diverse meteorological features over Europe (e.g., Kotlarski et al., 2005; Renfrew et al., 2009; Pfeiffer and Zängl, 2010). However, none of these works evaluate the NAO climatic impact simulated by the model over Europe. Thus, we devoted Sect. 4.1 to revise it and to ensure the ability of the climate simulation in this regard.

Boundary conditions of gas-phase pollutants concentration for CHIMERE are based on the global chemistry model LMDz-INCA2 (Szopa et al., 2009) developed by the Laboratoire des Sciences du Climat et l'Environnement (LSCE). A detailed description of the Interactive Chemistry and Aerosol (INCA) model is presented in Hauglustaine et al. (2004) and Folberth et al. (2006). For aerosols, boundary conditions are taken from the GOCART model (Chin et al., 2002). These boundary conditions consist of constant monthly mean data that are interpolated in the horizontal and vertical dimensions to force the major chemical concentrations at the boundaries of the CHIMERE domain. The use of constant climatological boundary conditions prevents the NAO impact on the aerosol concentration levels at the domain boundaries, thus avoiding the signals from the interannual variations in the large-scale inter-continental transport mechanisms related to the NAO phase. Hence this experimental design allows us to largely isolate the role of more local NAO-controlled processes (for instance, how the NAO influences the concentration of aerosols through its impact on local precipitation patterns), including also the transport of pollutants between different areas within our extensive domain.

Year-to-year varying anthropogenic emissions are derived from the EMEP database on a monthly basis (Vestreng et al., 2009). Natural emissions depend on climate conditions, and consequently they are modeled according to the MM5 meteorological outputs. However, the levels of air pollutants are estimated without considering possible changes on vegetation, land use or any feedback from the chemical compounds to the meteorological fields. Biogenic emissions were generated dynamically using MEGAN (Model of Emissions of Gases and Aerosols from Nature) (Guenther et al., 2006) with the parameterization form of the canopy environment model. The model estimates hourly isoprene, monoterpene, and other BVOC emissions based on plant functional type and as a function of temperature and ground-level shortwave radiation.

Beyond the several works supporting the ability of similar, but not identical, MM5-CHIMERE systems to reproduce the main air quality features over Europe (e.g., Monteiro et al., 2007; Flaounas et al., 2009; Péré et al., 2010), we have validated our particular setup of the modeling system by comparing a simulation covering the period 1990-2010 with EMEP observations (Tørseth et al., 2012). Although a thorough evaluation of the modeling approach is not included in the main objectives of this work, here we briefly show that the simulated series of aerosol concentrations correlate acceptably and capture a large fraction of the interannual variability of the observational series at the working timescale (i.e., seasonal). These two aspects are the most relevant for the assessment performed below, while systematic biases would not represent a major concern as they should be largely canceled when computing the composites of the NAO impact (see next Section). For brevity, we provide here the results for the simulated ground-level concentration of aerosols under two size thresholds, namely $\mathrm{PM}_{10}$ and $\mathrm{PM}_{2.5}$ (Fig. 1). For both cases, correlations between simulated and observational seasonal-averaged series are overwhelmingly above 0.8 , in most cases above 0.9 , both in winter and summer. Also, it is possible to verify that biases in the standard deviation of the simulated series are largely negligible in comparison to their mean values (being orders of magnitude smaller). It is also worth mentioning that normalized biases are always found to stay below $30 \%$ (not shown), which is in the top range expected (Pay et al., 2010). These results guarantee the 

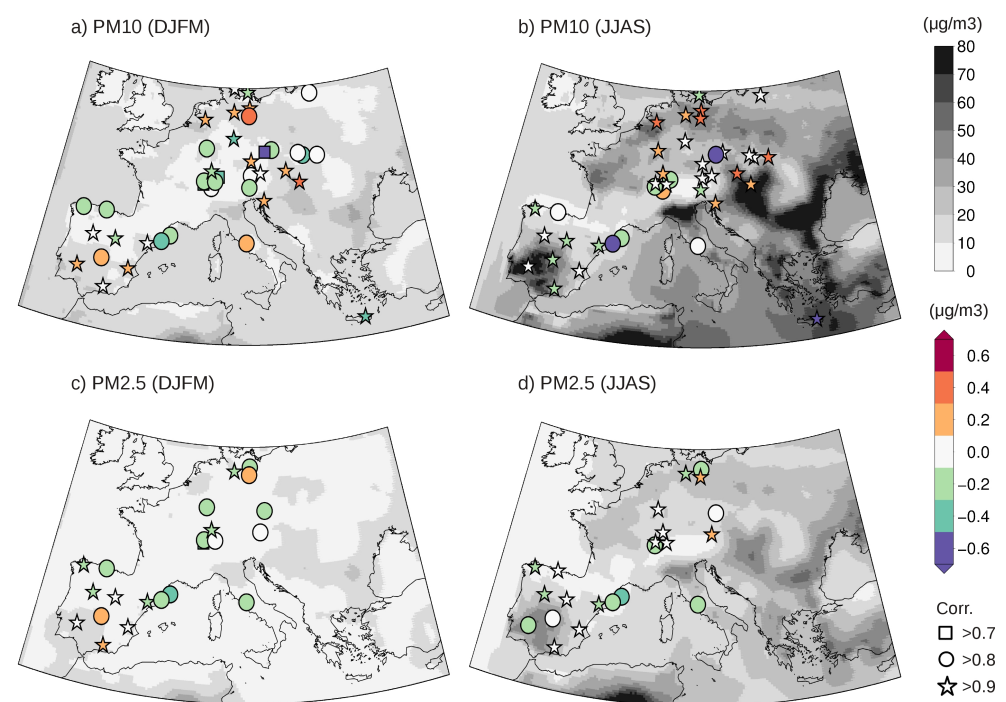

Fig. 1. Evaluation of the MM5-CHIMERE air quality modeling system described in Sect. 2.1. Gray shaded colors depict the simulated climatologies in $\mu \mathrm{g} \mathrm{m}^{-3}$ of $\mathrm{PM}_{10}$ (up) and $\mathrm{PM}_{2.5}$ (bottom) in winter (DJFM averages, left) and summer (JJAS averages, right). The comparison of the simulated series with EMEP observations is provided by symbols: their color shows the difference in the standard deviation of the series between the simulation and the observations (in $\mu \mathrm{g} \mathrm{m}^{-3}$ ), and their shape informs on the magnitude of the temporal correlation between the simulated and the observed series.

phase accordance (timing) between the simulated and observational series, their similar amplitude and, also, the quantitative accuracy of the simulated climatologies, hence making us confident of the suitability of the modeling system for the purpose of this study.

\subsection{Experimental setup}

In order to isolate the influence of climate variability on air quality, it becomes mandatory to avoid the signals derived from human policies. During the last decades, these policies have committed European countries to strongly reduce the emissions of contaminants to the atmosphere, which has caused strong non-natural trends in the observational series of almost all aerosol species (Vestreng et al., 2009; Tørseth et al., 2012). Hence, the impact of the NAO has been evaluated here based on a $30 \mathrm{yr}$ long MM5-CHIMERE simulation for which emissions were fixed at their 2005 mean levels. The simulated period (1970-1999) is not particularly significant in itself, but its length supports the robustness of our results from a climatic perspective.

\section{Methodology}

This assessment focuses on several aerosol families and species, namely natural inert aerosols (sea salt aerosols, SALT, and wind-blown and resuspended dust, DUST), secondary inorganic aerosols (sulfate, $\mathrm{SO}_{4}^{2-}$, nitrate, $\mathrm{NO}_{3}^{-}$, and ammonium, $\left.\mathrm{NH}_{4}^{+}\right)$, organic matter $(\mathrm{OM})$, with particular attention to secondary organic aerosols (SOA), and elemental carbon (EC). The total concentrations of $\mathrm{PM}_{10}$ and $\mathrm{PM}_{2.5}$ are also studied. The evaluation is restricted to the ground level.

The analysis is performed at the seasonal timescale for winter (December-to-March averages) and summer (June-toSeptember averages). This decision is based on previous tests performed at the monthly timescale showing the strongest responses in those months with very similar structures in each season. The remaining months from the two transitional seasons depicted intermediate and softer signals and thus are not included in the rest of the analysis.

Seasonal means (DJFM and JJAS averages) of the monthly NAO index provided by the Climate Prediction Center (CPC) from the National Ocean and Atmospheric Administration (NOAA) are used to define classes of positive and negative $\mathrm{NAO}$ phases $\left(\mathrm{NAO}^{+}\right.$and $\mathrm{NAO}^{-}$respectively) throughout the study period. Following a a common approach adopted in previous studies (e.g., Suski and Ridgway, 2007; Gouveia and Trigo, 2008), $\mathrm{NAO}^{+}\left(\mathrm{NAO}^{-}\right)$phases are defined as those with the NAO index above (below) the 70th (30th) percentile of the NAO index time series considered (Fig. 2). The use of these non-subjective thresholds in the definition of $\mathrm{NAO}^{+}$ and $\mathrm{NAO}^{-}$phases ensures the evenness between the number of events of each class (within the $30 \mathrm{yr}$ simulated period, 1970-1999, we retain 9 events of each class in each season) and prevents the unbalancing influence of potential long-term trends in the NAO index time series. On the other hand, it should be noticed that different data sources and/or methods for computing the NAO index may provide different values of it. In particular, we are aware that the CPC/NOAA NAO index is not based on the ECMWF data used to drive MM5 


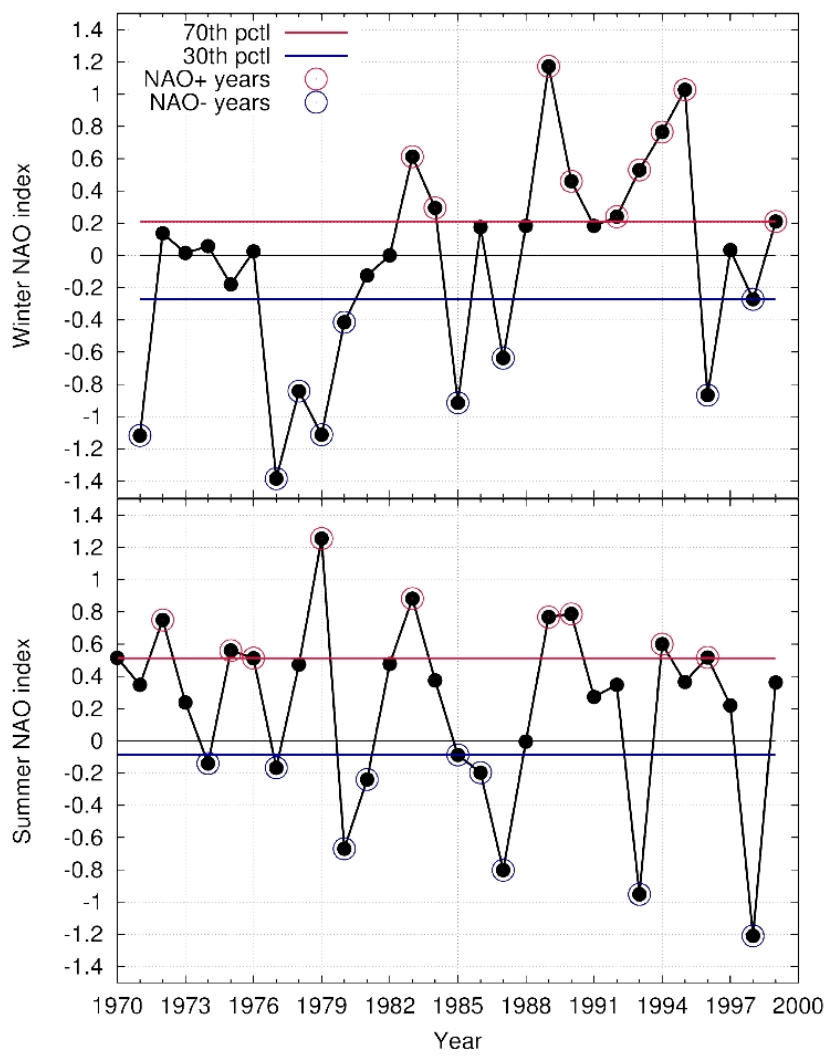

Fig. 2. Winter (top) and summer (bottom) NAO series for the period 1970-1999. The former are DJFM averages (therefore resulting in 29 values) and the latter are JJAS averages (resulting in 30 values). The red (blue) lines denote the 70th (30th) percentile value of each series, highlighting the years/values with a NAO index above (below) that percentile, i.e., those selected as $\mathrm{NAO}^{+}\left(\mathrm{NAO}^{-}\right)$events for the composites analysis.

in our modeling system. However, we confirmed that, at the timescale assessed here, this influence is negligible (Greatbatch and Rong, 2006). Hence, the choice of the CPC/NOAA NAO index for the present study is based on its easy access and its up-to-date computation approach, which in fact makes it widely used nowadays in studies focused on the recent past (e.g., Bladé et al., 2012; Jerez et al., 2013b; Pey et al., 2013).

The NAO impact on the assessed magnitudes is then evaluated through composites showing the differences in the mean fields between positive and negative NAO phases. Several significance controls are applied to these differences ensuring both their statistical robustness and physical consistence, so that they are just considered when fitting the following criteria: (1) being statistically significant above the $90 \%$ confidence level, and (2) being supported by statistically significant temporal correlations (above the $90 \%$ confidence level) between the NAO and the corresponding chemical component series. Statistical significance is evaluated by performing two-tailed $t$ tests for the null hypothesis of equal means or zero correlation respectively (Snedecor and Cochran, 1989). Moreover, the signal-to-noise ratio, defined as the ratio between the absolute value of the $\mathrm{NAO}^{+}$minus $\mathrm{NAO}^{-}$differences in a specific magnitude and the standard deviation of the whole seasonal series of such a magnitude, is considered as a relative measure of the importance of the NAO impact. In particular we have blurred the areas where the signal-to-noise ratio is below the unit. In the areas not blurred, the NAO impact exceeds one standard deviation of the series and hence we are likely moving from one tail to the other of the probability density function describing the variability in the levels of the assessed magnitude when the NAO phase changes.

\section{Results}

\subsection{Revisiting the NAO impact on atmospheric conditions}

Several works have been devoted to explore the role and signature of the NAO in the European climate (e.g., Hurrell, 1995; Hurrell and van Loon, 1997; Hurrell et al., 2003; Trigo et al., 2002, 2008). Indeed, the reported NAO impact on the climatic variables motivated the present study. Other works have shown a good capacity of the general circulation models to reproduce the large-scale patterns of this climatic impact over Europe particularly for winter (Osborn et al., 1999; Osborn, 2011; Hurrell et al., 2003) but also for summer (Bladé et al., 2012). Hence, this Section does not intend to provide novel insights, but essentially to evaluate the ability of our climate simulation (that is driving the CHIMERE run) to simulate the extensively reported NAO impact on the European atmospheric conditions. This fulfills two relevant requirements, namely to (1) guarantee that it is effectively able to reproduce the known NAO impact on the European climate, and (2) provide an appropriate context for the interpretation of the following results of the NAO impact on aerosol concentrations, since the analysis is specifically focused on those variables driving air pollution levels.

Figure 3 further confirms the expected NAO impact on the wind field, showing asymmetric responses in winter and summer. In winter, $\mathrm{NAO}^{+}\left(\mathrm{NAO}^{-}\right)$promotes a windy westerly flow in northern (southern) Europe (Fig. 3a, c), with the largest significant differences in the wind speed (above $10 \%$ ) appearing northward in the western sector of the domain (Fig. 3c). Conversely, in summer, $\mathrm{NAO}^{-}$phases are associated with a stronger westerly flow in northern Europe than $\mathrm{NAO}^{+}$phases (Fig. 3b, d), with differences in the wind module exceeding $5 \%$ and extending more eastward than in winter. Windier conditions associated to the $\mathrm{NAO}^{-}$phase prevail also in the southwest of the domain during summer, mainly in the surroundings of the Iberian Peninsula (differences about $5 \%$; Fig. 3d).

Consequences in precipitation, cloudiness and temperature derived from the former conditions are provided in 

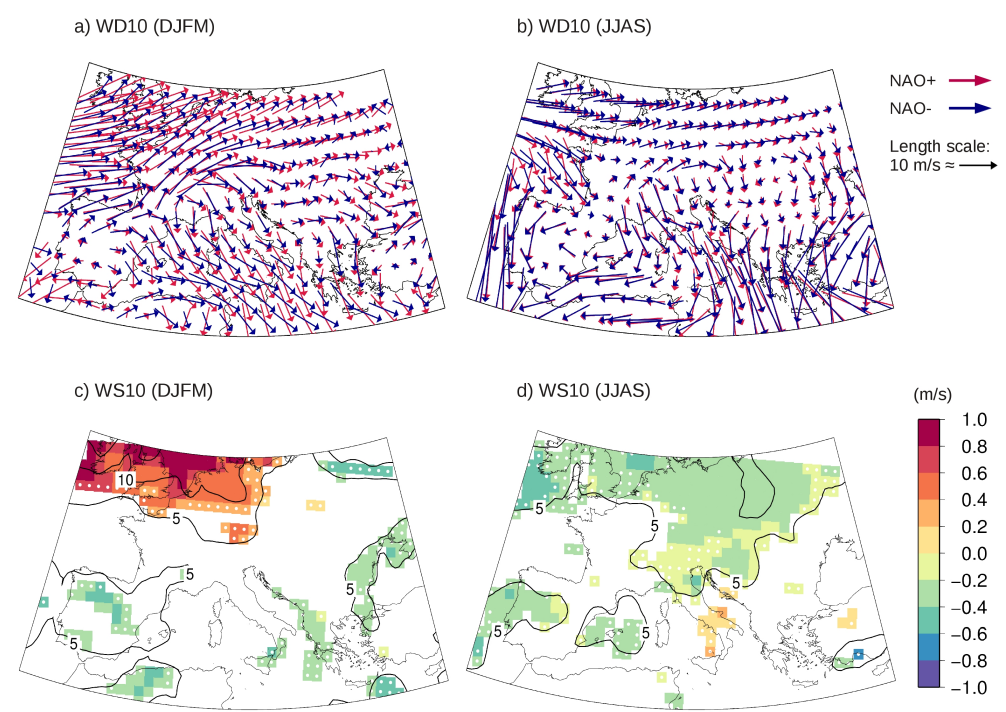

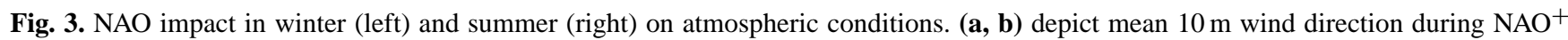
(red) and $\mathrm{NAO}^{-}$(blue) phases (the arrow's length is proportional to the wind speed). (c, d) provide the $\mathrm{NAO}^{+}$minus $\mathrm{NAO}^{-}$composites for

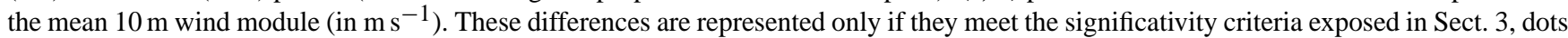
blur the values not representing a signal-to-noise ratio above 1, and contours depict differences expressed as percentage. Period considered: 1970-1999.

Fig. 4, as these variables play a key role on the levels of air pollutants in general, and aerosols in particular. Obtained patterns are in good agreement with previous works for winter (e.g., Osborn, 2011) or summer (Bladé et al., 2012) relating them to the westerly winds advection of humid air from the Atlantic, which favors the formation of clouds and enhances precipitation. $\mathrm{NAO}^{+}$minus $\mathrm{NAO}^{-}$differences in precipitation (Fig. 4a, b) are larger in winter than in summer, when they are overall negative and affect mainly southern Europe ranging west to east from $40 \%\left(50 \mathrm{~mm} \mathrm{month}^{-1}\right)$ to $20 \%$ $\left(20 \mathrm{~mm} \mathrm{month}^{-1}\right)$. In summer, these differences reach $20 \%$ (up to $30 \mathrm{~mm} \mathrm{month}^{-1}$ ) over large sectors of Europe, being negative in northern Europe while positive, and less important, in the southern affected areas. Consistently, the composites for the column integrated cloud water (a variable representative of cloudiness) (Fig. 4c, d) show negative values in southern Europe during winter (resembling the west to east gradient of the precipitation signal, with differences ranging from 30 to $10 \%$ ) and in northern areas during summer (differences around $10 \%$ ), and positive values in northwestern areas during winter (i.e., $\mathrm{NAO}^{+}$enhancing cloudiness there, around $20 \%$ ). Regarding the NAO impact on mean $2 \mathrm{~m}$ temperature, the most important signal consists of positive $\mathrm{NAO}^{+}$minus $\mathrm{NAO}^{-}$differences (up to $3 \mathrm{~K}$ ) largely spread over northern Europe in winter (Fig. 4e). Smaller negative (positive) differences (up just to $1 \mathrm{~K}$ ) appear also over some southernmost (northern) areas in winter (summer) (Fig. 4e, f).

These results support the ability of the climate simulation to reproduce the expected responses to the NAO phase, pro- viding a meaningful representation of how the atmospheric conditions vary between positive and negative NAO events that will be used to understand the NAO impact on aerosol concentration levels assessed in the next Section.

\subsection{NAO impact on mean ground-level aerosol concentrations}

$\mathrm{NAO}^{+}$minus $\mathrm{NAO}^{-}$composites of mean ground-level concentration of the various aerosol species are provided in Figs. 5-8. In general, the positive phase of NAO enhances aerosol concentrations in southern Europe during winter and in northern Europe during summer. These positive $\mathrm{NAO}^{+}$ minus $\mathrm{NAO}^{-}$differences match generally well the sectors characterized by negative signals in wind speed, precipitation and cloudiness (Figs. 3, 4). Thus such patterns can be well explained by the diluting effect of stronger winds and scavenging processes by an enhanced precipitation and by the inhibitory effect of enhanced cloudiness as it implies reduced shortwave solar radiation (a main precursor for photochemistry and biogenic emitting activity).

\subsubsection{Winter signals}

As a general rule, in winter, the regions holding the largest signals are predominantly located in the Mediterranean Basin, particularly over the Iberian Peninsula, northern Italy and the Balkans (Figs. 5-8, left column). There, results show increases in the mean concentration of all aerosol species during positive NAO phases exceeding the $50 \%$ of the mean levels during negative NAO phases, even doubling the latter 

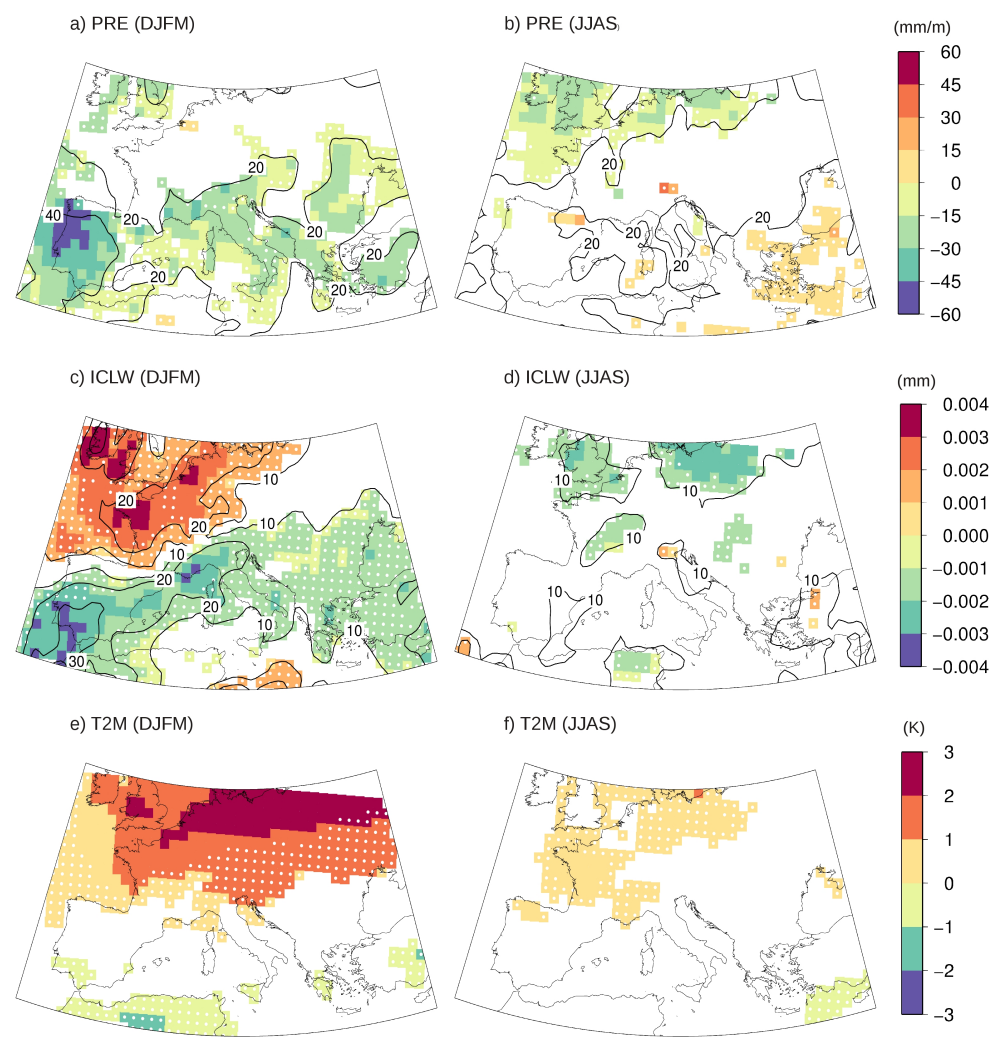

Fig. 4. As in Fig. $3 c$ and $\mathrm{d}$, here for $(\mathbf{a}, \mathbf{b})$ precipitation (in $\left.\mathrm{mm} \mathrm{month}^{-1}\right)$, (c, d) column integrated cloud water (in $\left.\mathrm{mm}\right)$ and $(\mathbf{e}, \mathbf{f}) 2 \mathrm{~m}$ temperature (in K).

on some occasions. In absolute values (although these should be taken with care due to our experimental design not accounting for real emission levels nor for long-range transports), the largest variations between NAO phases reach $5 \mu \mathrm{g} \mathrm{m}^{-3}$ and affect the inorganic compounds (DUST, $\mathrm{SO}_{4}^{2-}$, $\mathrm{NH}_{4}^{-}$and $\mathrm{NO}_{3}^{-}$), while the change in the concentration of carbonaceous material is just about $1 \mu \mathrm{g} \mathrm{m}^{-3}$. It is worth stressing the slight but still significant negative patches of $\mathrm{NAO}^{+}$minus $\mathrm{NAO}^{-}$differences in the British Islands and in northeastern Europe that appear in the patterns of OM and $\mathrm{EC}$, indicating a distinct response of these compounds to the same NAO phase depending on the latitude.

The NAO impact on $\mathrm{NO}_{3}^{-}$concentration levels is negligible over most of Europe. However, the removal effect of enhanced precipitation in northern Italy during $\mathrm{NAO}^{-}$phases seems to play a key cleaning role in this regard at this strong $\mathrm{NO}_{3}^{-}$-emitting area.

Contrary to the rest of aerosol species, enhanced winds promote the formation of SALT (sea salt aerosol emissions depends on the cube of the wind speed), thus leading to higher concentrations. This is mainly observed over the water mass areas, with $\mathrm{NAO}^{+}$leading to $40 \%$ higher SALT concentrations in the surroundings of the British Islands, which matches with the $\mathrm{NAO}^{+}$enhanced winds observed in this area (Fig. 3c), but diminishing them in the south- ern Mediterranean (Fig. 5a). Singular positive signals appear also in the Gulf of Genoa (northwestward of Italy) and the strait of Gibraltar (southward of Spain). Regarding these three latter cases, it can be roughly appreciated in Fig. 3a that $\mathrm{NAO}^{+}$promotes windier conditions over the mentioned areas (longer arrows) than $\mathrm{NAO}^{-}$, although these differences in wind speed do not remain after applying the significativity controls, as they are not reflected in Fig. 3c.

The NAO impact on winter air quality is appreciable in the various size classes of particulate matter. Figure $8 \mathrm{a}$ and c shows that $\mathrm{NAO}^{+}$enhances $20-40 \%$ the concentrations of both $\mathrm{PM}_{10}$ and $\mathrm{PM}_{2.5}$ in the southern European regions (where the PM climatologies present the higher values and the number of exceedances of the limit values for the protection to human health are more frequent), and also, but to a smaller extent, in some northernmost areas. Therefore, the winter NAO phase has a clear impact on the air-qualityrelated human health risk in this season.

\subsubsection{Summer signals}

In summer, the highest signals within our domain appear in the British Islands, northern France, Belgium, the Netherlands, northern Germany and northern Poland (Figs. 5-8, right column). It is also interesting to see the recurrent 

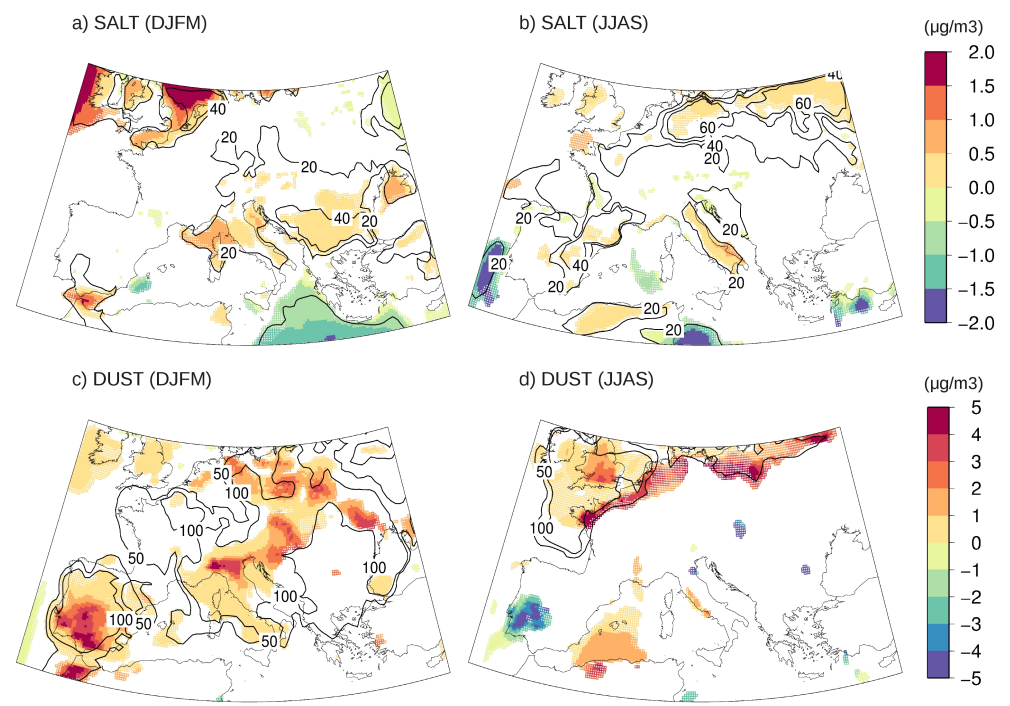

Fig. 5. NAO impact in winter (left) and summer (right) on mean ground levels of natural inert aerosols: $\mathrm{NAO}^{+}$minus $\mathrm{NAO}^{-}$composites $^{-}$ for (a, b) SALT and (c, d) DUST. Differences in $\mu \mathrm{g} \mathrm{m}^{-3}$ are represented only if they meet the significativity criteria exposed in Sect. 3, dots blur the values not representing a signal-to-noise ratio above 1, and contours depict differences expressed as percentage. Period considered: 1970-1999.

positive signals appearing over Italy also in this season, although their patchy nature should be acknowledged.

As in winter, differences in the aerosol concentrations between NAO phases are up to $100 \%$, demonstrating the profound impact of the NAO in this area/season. Likewise, the obtained $\mathrm{NAO}^{+}$related increments are, in absolute values, about (even over) $5 \mu \mathrm{g} \mathrm{m}^{-3}$ for each inorganic species except SALT (which shows smaller signals, Fig. 5b). The $\mathrm{NAO}^{+}$ related increases in the concentration of the organic and carbonaceous aerosols are also a bit smaller (when they are expressed in $\mu \mathrm{g} \mathrm{m}^{-3}$ ).

It is worth stressing the signal in mean SOA levels (Fig. 7d), which can be doubly related to the reducing effect of $\mathrm{NAO}^{+}$in precipitation (Fig. 4b), as it prevents wet deposition, and to the increased temperatures during $\mathrm{NAO}^{+}$ enhancing the biogenic emissions (such as isoprene and monoterpenes), which leads to higher levels of biogenic SOA.

The $\mathrm{NO}_{3}^{-}$signal appears again mainly restricted to the stronger emitting areas, being located in this season between northern France, Belgium and Germany (Fig. 6d). There, the reduced precipitation during $\mathrm{NAO}^{+}$events doubles the concentrations of nitrate in comparison to the levels during $\mathrm{NAO}^{-}$phases.

SALT depicts slight variations associated to the NAO phase in summer (around $0.5 \mu \mathrm{g} \mathrm{m}^{-3}$, Fig. 5b). However, contrary to the winter analysis, significant impact areas are now located over land areas and not over the sea, namely in eastern Iberia and Italy and in northeastern Europe, where the results show positive $\mathrm{NAO}^{+}$minus $\mathrm{NAO}^{-}$differences.
Lastly, $\mathrm{PM}_{2.5}$ and $\mathrm{PM}_{10}$ show differences of up to 10 and $20 \mu \mathrm{g} \mathrm{m}^{-3}$ respectively (higher concentrations during $\mathrm{NAO}^{+}$), mainly concentrated in the northernmost areas of the domain and representing variations of up to $20-40 \%$ between NAO phases (Fig. 8b, d) as observed for winter.

\section{Conclusions}

This study establishes the strong impact that the NAOrelated local atmospheric processes have on mean groundlevel aerosol concentrations over Europe. For that we use a $30 \mathrm{yr}$ long air quality simulation with a spatial resolution of $25 \mathrm{~km}$ over the target region in which the masking influence of human policies aimed at reducing emissions has been intentionally omitted. Moreover, this simulation allows us to isolate the influence of the NAO impact through the local processes, i.e., those taking place within the boundaries of the domain, as the boundary conditions for the aerosol concentration levels did not vary from year to year in our experimental design. In this sense, our results should not be considered deterministic given that the whole real picture does include variations in both emissions and long-range pollutant transport. In turn, by opting to narrowly focus on the natural and local processes as they are governed by the NAO, we achieved a deep understanding of their isolated role.

The results show impacts with asymmetries in both time (i.e., between seasons) and space (i.e., between northern and southern areas). In winter, higher ground-level concentrations of all aerosol species (except for sea salt) are observed around the Mediterranean Basin during the positive NAO phases, while these signals are shifted northward in the 

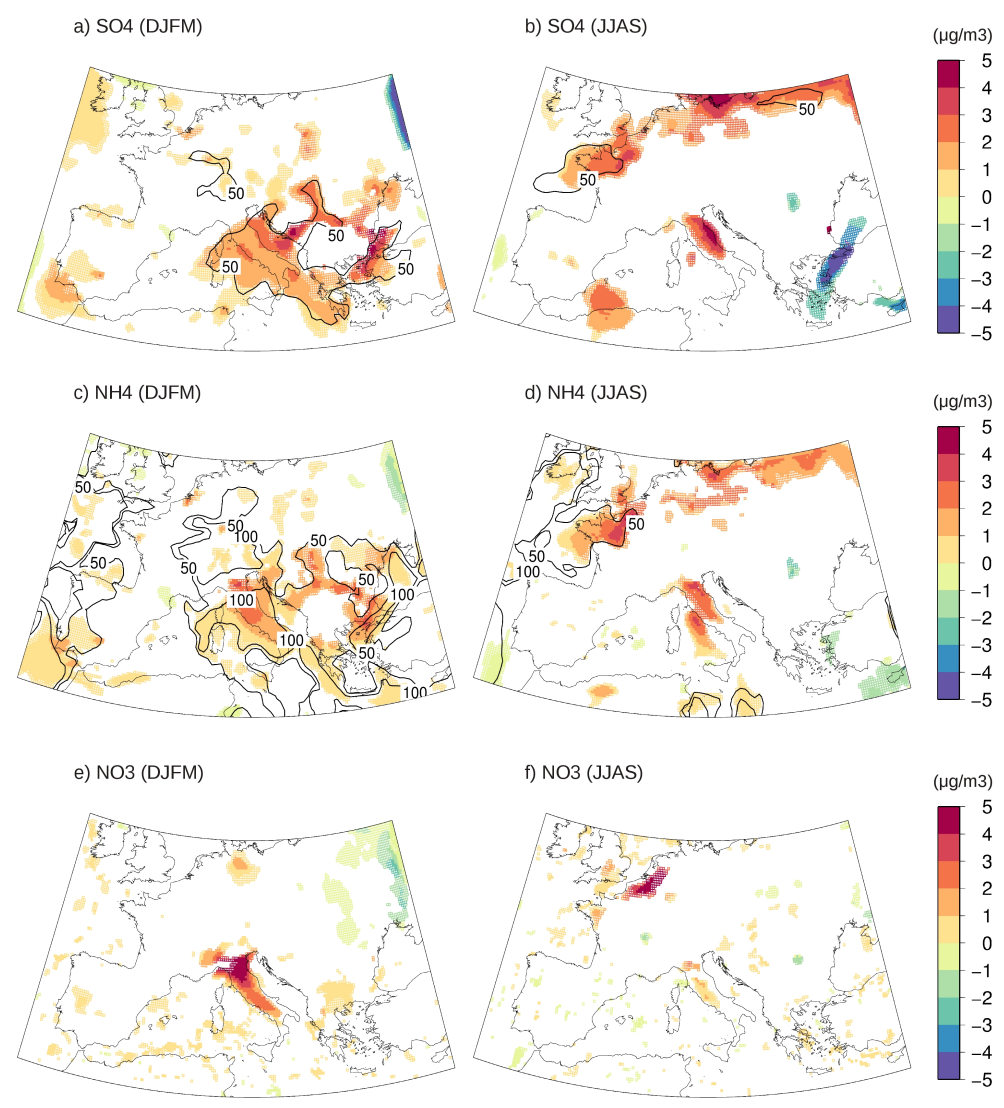

Fig. 6. As in Fig. 5, here for secondary inorganic aerosols: (a, b) $\mathrm{SO}_{4}^{2-},(\mathbf{c}, \mathbf{d}) \mathrm{NH}_{4}^{+}$and $(\mathbf{e}, \mathbf{f}) \mathrm{NO}_{3}^{-}$.

summer season. These differences involve variations up to and over $100 \%$ in the mean levels of each species; about $20-40 \%$ for $\mathrm{PM}_{10}$ and $\mathrm{PM}_{2.5}$. Eventually, softer signals of opposite sign (i.e., $\mathrm{NAO}^{-}$enhancing the ground-level concentration of aerosols) are observed in northern (southern) areas during winter (summer).

The causes for these NAO-related variations in the levels of aerosols have to be sought in a multiplicity of climatic factors varying between NAO positive/negative phases, namely: (1) increased/reduced temperature (particularly in northern Europe), (2) different distribution of the precipitation patterns across Europe, (3) changes in the photolysis of primary and secondary pollutants due to changes in cloudiness, and (4) the cleaning effect of enhanced winds. According to the results of this work and based on the established relationship between meteorological fields and air quality (e.g., Wu et al., 2008; Katragkou et al., 2010; Jiménez-Guerrero et al., 2012; Manders et al., 2012), the NAO impact on climate supports the NAO impact on aerosol concentrations as follows. Changes in precipitation drive the NAO impact on the concentration of most aerosol components (in both northern and southern Europe), with the decrease in the precipitation modeled during $\mathrm{NAO}^{+}$phases leading to a regional increase in the levels of secondary inorganic aerosols and mineral matter (e.g., Jiménez-Guerrero et al., 2012; Manders et al., 2012). Additionally, the weaker winds associated to the $\mathrm{NAO}^{+}$events favor the increase of particulate matter in polluted regions such as large cities or entire industrial regions (e.g., Po Valley in northern Italy and the Rhine-Ruhr area in northern Germany and the Netherlands). Also, the enhanced oxidative capacity of the atmosphere with high temperatures causes $\mathrm{SO}_{2}$ gas-phase emissions to turn into the particulate phase, thus increasing sulfate concentrations as observed during $\mathrm{NAO}^{+}$phases in southern (northern) regions during winter (summer). Lastly, the levels of SOA are conditioned by the dependence of biogenic emissions on the climatological patterns of variability. In this sense, SOA over Europe is mainly driven by the warming-induced increase in biogenic emitting activity. Although vegetation is kept invariable in the simulation analyzed here, MEGAN estimations of these emissions strongly depend on shortwave radiation and temperature (Guenther et al., 2006), which are substantially conditioned by the cloudiness and thereby by the NAO. Accordingly, the lower cloudiness associated to $\mathrm{NAO}^{+}$phases mostly in southern Europe arises as a main driver for the secondary conversion of aerosols.

These results expand the knowledge of the relationship between the climatic conditions and air quality levels, 

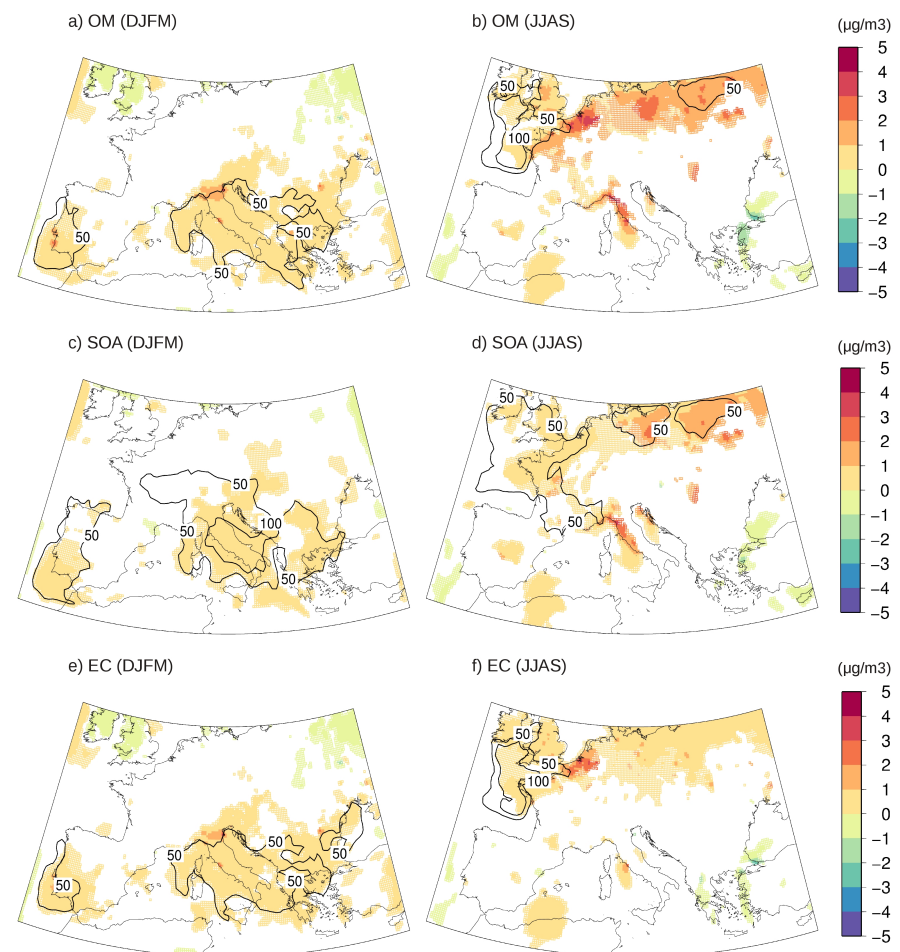

Fig. 7. As in Fig. 5, here for organic materials: (a, b) OM, (c, d) SOA and (e, f) EC.
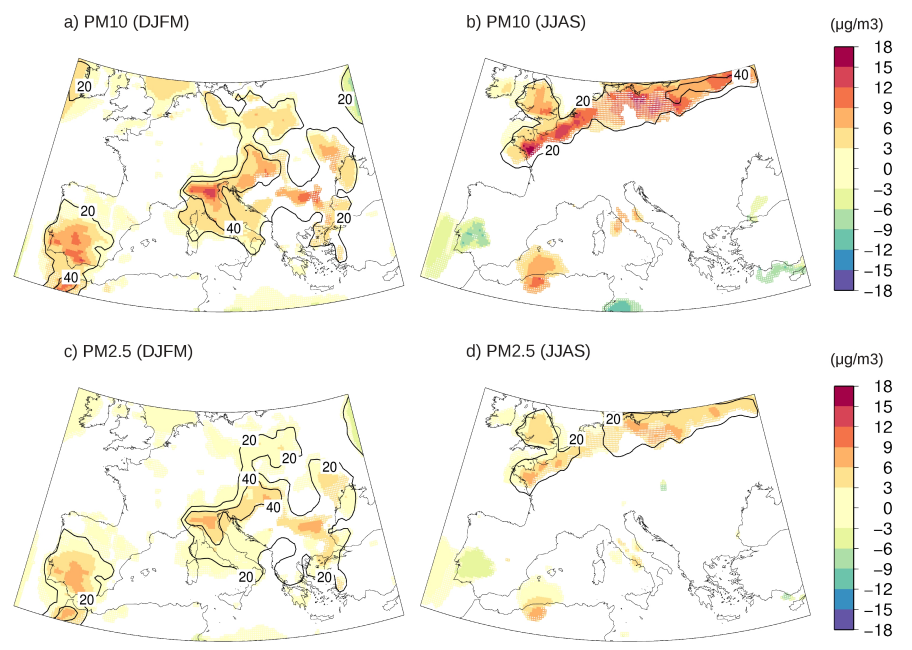

Fig. 8. As in Fig. 5, here for particulate matter: (a, b) $\mathrm{PM}_{10}$ and (c, d) $\mathrm{PM}_{2.5}$.

highlighting that the great dependence of the European climate on the NAO phase has associated strong natural variations in the aerosol concentration levels. Additionally, we are confident that these results can provide the basis for inferring future air quality scenarios from either future projections or short-to-medium range forecasts of the NAO. Although the potential predictability of the NAO or other large-scale climatic indexes is still moderate (Gámiz-Fortis et al., 2002; Saunders and Quian, 2002) and future projections of the
NAO differ much from one experiment to the other (Hurrell et al., 2003), there are realistic expectations that this would be largely improved in the near future (e.g., Brands et al., 2012).

Acknowledgements. This work was funded by the Portuguese Foundation of Science and Technology (FCT) (project ENAC PTDC/AAC-CLI/103567/2008), the Spanish Ministry of Economy and Competitiveness and the Fondo Europeo de Desarrollo 
Regional (FEDER) (project CORWES CGL2010-22158-C02-02). P. Jiménez-Guerrero acknowledges the Ramón y Cajal programme.

Edited by: A. Pozzer

\section{References}

Ballester, F., Medina, S., Boldo, E., Goodman, P., Neuberger, M., Iñiguez, C., and Künzli, N.: Reducing ambient levels of fine particulates could substantially improve health: a mortality impact assessment for 26 European cities, J. Epidemiol. Commun. H., 62, 98-105, 2008.

Bessagnet, B., Hodzic, A., Vautard, R., Beekmann, M., Cheinet, S., Honore, C., Liousse, C., and Rouil, L.: Aerosol modelling with CHIMERE - Preliminary evaluation at the continental scale, Atmos. Environ., 38, 2803-2817, 2004.

Bladé, I., Liebmann, B., Fortuny, D., and van Oldenborgh, G. J.: Observed and simulated impacts of the summer NAO in Europe: implications for projected drying in the Mediterranean region, Clim. Dynam., 39, 709-727, 2012.

Brands, S., Manzanas, R., Gutiérrez, J. M., and Cohen, J.: Seasonal Predictability of Wintertime Precipitation in Europe Using the Snow Advance Index, J. Climate, 25, 4023-4028, 2012.

Carvalho, A., Monteiro, A., Solman, S., Miranda, A. I., and Borrego, C.: Climate-driven changes in air quality over Europe by the end of the 21st century, with special reference to Portugal, Environmental Science and Policy, 13, 445-458, 2010.

Chiacchio, M. and Wild, M.: Influence of NAO and clouds on longterm seasonal variations of surface solar radiation in Europe, J. Geophys. Res., 115, D00D22, doi:10.1029/2009JD012182, 2010.

Chin, M., Ginoux, P., Kinne, S., Torres, O., Holben, B. N., Duncan, B. N., Martin, R. V., Logan, J. A., Higurashi, A., and Nakajima, T.: Tropospheric Aerosol Optical Thickness from the GOCART Model and Comparisons with Satellite and Sun Photometer Measurements, J. Atmos. Sci., 59, 461-483, 2002.

Christoudias, T., Pozzer, A., and Lelieveld, J.: Influence of the North Atlantic Oscillation on air pollution transport, Atmos. Chem. Phys., 12, 869-877, doi:10.5194/acp-12-869-2012, 2012.

Colette, A., Bessagnet, B., Vautard, R., Szopa, S., Rao, S., Schucht, S., Klimont, Z., Menut, L., Clain, G., Meleux, F., Curci, G., and Rouill, L.: European atmosphere in 2050, a regional air quality and climate perspective under CMIP5 scenarios, Atmos. Chem. Phys., 13, 7451-7471, doi:10.5194/acp-13-7451-2013, 2013.

Cusack, M., Alastuey, A., Pérez, N., Pey, J., and Querol, X.: Trends of particulate matter $\left(\mathrm{PM}_{2.5}\right)$ and chemical composition at a regional background site in the Western Mediterranean over the last nine years (2002-2010), Atmos. Chem. Phys., 12, 8341-8357, doi:10.5194/acp-12-8341-2012, 2012.

Dayan, U.: Impacts of the NAO on atmospheric pollution in the Mediterranean Basin, in: Advances in Global Change Research: Hydrological, Socioeconomic and Ecological Impacts of the North Atlantic Oscillation in the Mediterranean Region, edited by: Vicente-Serrano, S. M. and Trigo, R. M., Springer, 171-181, 2011.

Dayan, U., Ziv, B., Shoob, T., and Enzel, Y.: Suspended dust over southeastern Mediterranean and its relation to atmospheric circulations, Int. J. Climatol., 28, 915-924, 2008.
Derognat, C., Beekmann, M., Baeumle, M., Martin, D., and Schmidt, H.: Effect of biogenic volatile organic compound emissions on tropospheric chemistry during the atmospheric pollution over the Paris Area (ESQUIF) campaign in the Ile-de-France region, J. Geophys. Res., 108, 8560, doi:10.1029/2001JD001421, 2003.

Eckhardt, S., Stohl, A., Beirle, S., Spichtinger, N., James, P., Forster, C., Junker, C., Wagner, T., Platt, U., and Jennings, S. G.: The North Atlantic Oscillation controls air pollution transport to the Arctic, Atmos. Chem. Phys., 3, 1769-1778, doi:10.5194/acp-31769-2003, 2003.

Flaounas, E., Coll, I., Armengaud, A., and Schmechtig, C.: The representation of dust transport and missing urban sources as major issues for the simulation of PM episodes in a Mediterranean area, Atmos. Chem. Phys., 9, 8091-8101, doi:10.5194/acp-9-80912009, 2009.

Folberth, G. A., Hauglustaine, D. A., Lathière, J., and Brocheton, F.: Interactive chemistry in the Laboratoire de Météorologie Dynamique general circulation model: model description and impact analysis of biogenic hydrocarbons on tropospheric chemistry, Atmos. Chem. Phys., 6, 2273-2319, doi:10.5194/acp-62273-2006, 2006.

Folland, C. K., Knight, J., Linderholm, H. W., Fereday, D., Ineson, S., and Hurrell, J. W.: The summer North Atlantic Oscillation: past, present, and future, J. Climate, 22, 1082-1103, 2009.

Forkel, R., Werhahn, J., Hansen, A. B., McKeen, S., Peckham, S., Grell, G., and Suppan, P.: Effect of aerosol-radiation feedback on regional air quality - a case study with WRF/Chem, Atmos. Environ., 53, 202-211, 2012.

Gámiz-Fortis, S. R., Pozo-Vázquez, D., Esteban-Parra, M. J., and Castro-Díez, Y.: Spectral characteristics and predictability of the NAO assessed through Singular Spectral Analysis, J. Geophys. Res., 107, 4685, doi:10.1029/2001JD001436, 2002.

Gómez-Navarro, J. J., Montávez, J. P., Jerez, S., Jiménez-Guerrero, P., Lorente-Plazas, R., González-Rouco, J. F., and Zorita, E.: A regional climate simulation over the Iberian Peninsula for the last millennium, Clim. Past, 7, 451-472, doi:10.5194/cp-7-451-2011, 2011.

Gouveia, C. and Trigo, R. M.: Infuence of climate variability on wheat production in Portugal, in: geoENV VI - Geostatistics for Environmental Applications, edited by: Soares, A., Pereira, M. J., and Dimitrakopoulos, R., Springer, 335-345, 2008.

Greatbatch, R. J. and Rong, P. P.: Discrepancies between different Northern Hemisphere summer atmospheric data products, J. Climate, 19, 1261-1273, 2006.

Grell, G. A., Dudhia, J., and Stauffer, D. R.: A description of the fifth-generation Penn State/NCAR Mesoscale Model (MM5), NCAR Tech. Note 398+STR, Natl. Cent. For Atmos. Res, Boulder, Colo., 1994.

Guenther, A., Karl, T., Harley, P., Wiedinmyer, C., Palmer, P. I., and Geron, C.: Estimates of global terrestrial isoprene emissions using MEGAN (Model of Emissions of Gases and Aerosols from Nature), Atmos. Chem. Phys., 6, 3181-3210, doi:10.5194/acp-63181-2006, 2006.

Hauglustaine, D. A., Hourdin, F., Jourdain, L., Filiberti, M. A., Walters, S., Lamarque, J.-F., and Holland, E. A.: Interactive chemistry in the Laboratoire de Meteorologie Dynamique general circulation model: Description and background tropo- 
spheric chemistry evaluation, J. Geophys. Res., 109, D04314, doi:10.1029/2003JD003957, 2004.

Hedegaard, G. B., Christensen, J. H., and Brandt, J.: The relative importance of impacts from climate change vs. emissions change on air pollution levels in the 21st century, Atmos. Chem. Phys., 13, 3569-3585, doi:10.5194/acp-13-3569-2013, 2013.

Hurrell, J.: Decadal trends in North Atlantic Oscillation and relationship to regional temperature and precipitation, Science, 269, 676-679, 1995.

Hurrell, J. and Van Loon, H.: Decadal variations in climate associated with the North Atlantic Oscillation, Climatic Change, 36, 301-326, 1997.

Hurrell, J., Kushnir, Y., Ottersen, G., and Visbeck, M.: The North Atlantic Oscillation - Climatic Significance and Environmental Impact, Geophysical Monograph Series, No. 134, American Geophysical Union, 2003.

Jacob, D. J. and Winner, D. A.: Effect of climate change on air quality, Atmos. Environ., 43, 51-63, 2009.

Jerez, S., Montavez, J. P., Jiménez-Guerrero, P., Gomez-Navarro, J. J., Lorente-Plazas, R., and Zorita, E.: A multi-physics ensemble of present-day climate regional simulations over the Iberian Peninsula, Clim. Dynam., 40, 3023-3046, $2013 \mathrm{a}$.

Jerez, S., Trigo, R. M., Vicente-Serrano, S. M., Pozo-Vázquez, D., Lorente-Plazas, R., Lorenzo-Lacruz, J., Santos-Alamillos, F., and Montávez, J. P.: The impact of the North Atlantic Oscillation on renewable energy resources in southwestern Europe, J. Appl. Meteorol. Clim., 52, 2204-2225, 2013 b.

Jimeìnez-Guerrero, P., Goìmez-Navarro, J. J., Jerez, S., LorentePlazas, R., Garciìa-Valero, J. A., and Montaìvez, J. P.: Isolating the effects of climate change in the variation of secondary inorganic aerosols (SIA) in Europe for the 21st century (1991-2100), Atmos. Environ., 45, 1059-1063, 2011.

Jiménez-Guerrero, P., Montávez, J. P., Gómez-Navarro, J. J., Jerez, S., and Lorente-Plazas, R.: Impacts of climate change on ground level gas-phase pollutants and aerosols in the Iberian Peninsula for the late XXI century, Atmos. Environ., 55, 483-495, 2012.

Juda-Rezler, K., Reizer, M., Huszar, P., Krüger, B., Zanis, P., Syrakov, D., Katragkou, E., Trapp, W., Melas, D., Chervenkov, H., Tegoulias, I., and Halenka, T.: Modelling the effects of climate change on air quality over Central and Eastern Europe: concept, evaluation and projections, Clim. Res., 53, 179-203, 2012.

Katragkou, E., Zanis, P., Tegoulias, I., Melas, D., Kioutsioukis, I., Krüger, B. C., Huszar, P., Halenka, T., and Rauscher, S.: Decadal regional air quality simulations over Europe in present climate: near surface ozone sensitivity to external meteorological forcing, Atmos. Chem. Phys., 10, 11805-11821, doi:10.5194/acp10-11805-2010, 2010.

Kotlarski, S., Block, A., Böhm, U., Jacob, D., Keuler, K., Knoche, R., Rechid, D., and Walter, A.: Regional climate model simulations as input for hydrological applications: evaluation of uncertainties, Adv. Geosci., 5, 119-125, doi:10.5194/adgeo-5-1192005, 2005.

Manders, A. M. M., van Meijgaard, E., Mues, A. C., Kranenburg, R., van Ulft, L. H., and Schaap, M.: The impact of differences in large-scale circulation output from climate models on the regional modeling of ozone and PM, Atmos. Chem. Phys., 12, 9441-9458, doi:10.5194/acp-12-9441-2012, 2012.

Meier, J., Tegen, I., Heinold, B., and Wolke, R.: Direct and semidirect radiative effects of absorbing aerosols in Europe: Re- sults from a regional model, Geophys. Res. Lett., 39, L09802, doi:10.1029/2012GL050994, 2012.

Monteiro, A., Miranda, A. I., Borrego, C., Vautard, R., Ferreira, J., and Perez, A. T.: Long-term assessment of particulate matter using chimere model, Atmos. Environ., 41, 7726-7738, 2007.

Moulin, C., Lambert, C. E., Dulac, F., and Dayan, U.: Control of atmospheric export of dust from North Africa by the North Atlantic Oscillation, Nature, 387, 691-694, 1997.

Nenes, A., Pandis, S. N., and Pilinis, C.: ISORROPIA: A new thermodynamic equilibrium model for multiphase multicomponent inorganic aerosols, Aquat. Geochem., 4, 123-152, 1998.

Osborn, T. J.: Variability and Changes in the North Atlantic Oscillation Index, Adv. Glob. Change Res., 46, 9-22, 2011.

Osborn, T. J., Briffa, K. R., Tett, S. F. B., Jones, P. D., and Trigo, R. M.: Evaluation of the North Atlantic Oscillation as simulated by a coupled climate model, Clim. Dynam., 15, 685-702, 1999.

Pay, M. T., Piot, M., Jorba, O., Gassó, S., Gonçalves, M., Basart, S., Dabdub, D., Jiménez-Guerrero, P., and Baldasano, J. M.: A full year evaluation of the CALIOPE-EU air quality modeling system over Europe for 2004, Atmos. Environ., 44, 3322-3342, 2010.

Péré, J. C., Mallet, M., Pont, V., and Bessagnet, B.: Evaluation of an aerosol optical scheme in the chemistry-transport model CHIMERE, Atmos. Environ., 44, 3688-3699, 2010.

Pey, J., Querol, X., Alastuey, A., Forastiere, F., and Stafoggia, M.: African dust outbreaks over the Mediterranean Basin during 2001-2011: $\mathrm{PM}_{10}$ concentrations, phenomenology and trends, and its relation with synoptic and mesoscale meteorology, Atmos. Chem. Phys., 13, 1395-1410, doi:10.5194/acp-13-13952013, 2013.

Pfeiffer, A. and Zängl, G.: Validation of climate-mode MM5simulations for the European Alpine Region, Theor. Appl. Climatol., 101, 93-108, 2010.

Pope, C. A. and Dockery, D. W.: Health effects of fine particulate air pollution: lines that connect, JAPCA-J. Air Waste Ma., 56, 709-742, 2006.

Pope, C. A., Ezzati, M., and Dockery, D. W.: Fine-particulate air pollution and life expectancy in the United States, New Engl. J. Med., 360, 376-386, 2009.

Renfrew, I. A., Petersen, G. N., Sproson, D. A. J., Moore, G. W. K., Adiwidjaja, H., Zhang, S., and North, R.: A comparison of aircraft-based surface-layer observations over Denmark Strait and the Irminger Sea with meteorological analyses and QuikSCAT winds, Q. J. Roy. Meteor. Soc., 135, 2046-2066, 2009.

Rouil, L., Honore, C., Vautard, R., Beekmann, M., Bessagnet, B., Malherbe, L., Meleux, F., Dufour, A., Elichegaray, C., Flaud J.M., Menut, L., Martin, D., Peuch, A., Peuch, V.-H., and Poisson, N.: PREV'AIR, an operational forecasting and mapping system for air quality in Europe, B. Am. Meteorol. Soc., 90, 73-83, 2009.

Sanchez-Lorenzo, A., Calbó, J., and Martin-Vide, J.: Spatial and temporal trends in sunshine duration over Western Europe (1938-2004), J. Climate, 21, 6089-6098, 2008.

Saunders, M. A. and Qian, B.: Seasonal predictability of the winter NAO from north Atlantic sea surface temperatures, Geophys. Res. Lett., 29, 2049, doi:10.1029/2002GL014952, 2002.

Snedecor, G. W. and Cochran, W. G.: Statistical Methods, 8th Edition, ed. Iowa State University Press, 1989. 
Suski, C. D. and Ridgway, M. S.: Climate and body size influence nest survival in a fish with parental care, J. Anim. Ecol., 76, 730$739,2007$.

Szopa, S., Foret, G., Menut, L., and Cozic, A.: Impact of large scale circulation on European summer surface ozone and consequences for modelling forecast, Atmos. Environ., 43, 11891195, 2009.

Tørseth, K., Aas, W., Breivik, K., Fjæraa, A. M., Fiebig, M., Hjellbrekke, A. G., Lund Myhre, C., Solberg, S., and Yttri, K. E.: Introduction to the European Monitoring and Evaluation Programme (EMEP) and observed atmospheric composition change during 1972-2009, Atmos. Chem. Phys., 12, 5447-5481, doi:10.5194/acp-12-5447-2012, 2012.

Trigo, I. F.: Climatology and interannual variability of storm-tracks in the Euro-Atlantic sector: a comparison between ERA-40 and NCEP/NCAR reanalyses, Clim. Dynam., 26, 127-143, 2006.

Trigo, R. M., Osborn, T. J., and Corte-Real, J. M.: The North Atlantic Oscillation influence on Europe: climate impacts and associated physical mechanisms, Clim. Res., 20, 9-17, 2002.

Trigo, R. M., Valente, M. A., Trigo, I. F., Miranda, P. M. A., Ramos, A. M., Paredes, D., and García-Herrera, R.: The impact of north Atlantic wind and cyclone trends on European precipitation and significant wave height in the Atlantic, Ann. NY Acad. Sci., 1146, 212-234, 2008.

Uppala, S. M., Källberg, P. W., Simmons, A. J., Andrae, U., Bechtold, V., Fiorino, M., Gibson, J. K., Haseler, J., Hernandez, A., Kelly, G. A., Li, X., Onogi, K., Saarinen, S., Sokka, N., Allan, R. P., Andersson, E., Arpe, K., Balmaseda, M. A., Beljaars, A. C. M., Van De Berg, L., Bidlot, J., Bormann, N., Caires, S., Chevallier, F., Dethof, A., Dragosavac, M., Fisher, M., Fuentes, M., Hagemann, S., Hólm, E., Hoskins, B. J., Isaksen, L., Janssen, P. A. E. M., Jenne, R., Mcnally, A. P., Mahfouf, J.-F., Morcrette, J.-J., Rayner, N. A., Saunders, R. W., Simon, P., Sterl, A., Trenberth, K. E., Untch, A., Vasiljevic, D., Viterbo, P., and Woollen, J.: The ERA-40 re-analysis, Q. J. Roy. Meteorol. Soc., 131, 2961-3012, 2005.
Van Dingenen, R., Dentener, F. J., Raes, F., Krol, M. C., Emberson, L., and Cofala, J.: The global impact of ozone on agricultural crop yields under current and future air quality legislation, Atmos. Environ., 43, 604-618, 2009.

Vestreng, V., Ntziachristos, L., Semb, A., Reis, S., Isaksen, I. S. A., and Tarrasón, L.: Evolution of $\mathrm{NO}_{x}$ emissions in Europe with focus on road transport control measures, Atmos. Chem. Phys., 9, 1503-1520, doi:10.5194/acp-9-1503-2009, 2009.

Vicente-Serrano, S. M. and Trigo, R. M. (Eds.): Advances in Global Change Research. Hydrological, Socioeconomic and Ecological Impacts of the North Atlantic Oscillation in the Mediterranean Region, Springer, 2011.

Wanner, H., Brönnimann, S., Casty, C., Gyalistras, D., Luterbacher, J., Schmutz, C., Stephenson D. B., and Xoplaki, E.: North Atlantic Oscillation - concepts and studies, Surv. Geophys., 22, 321-382, 2001.

Wu, S., Mickley, L. J., Jacob, D. J., Rind, D., and Streets, D. G.: Effects of 2000-2050 changes in climate and emissions on global tropospheric ozone and the policy-relevant background surface ozone in the United States, J. Geophys. Res., 113, D18312, doi:10.1029/2007JD009639, 2008. 